IP Periodica Polytechnica

Transportation Engineering

47(4), pp. 295-301, 2019

https://doi.org/10.3311/PPtr.12105

Creative Commons Attribution (i)

RESEARCH ARTICLE

\section{Influencing the Mechanical Properties of Engine and Vehicle Constructions Alloy with Laser Surface Heating}

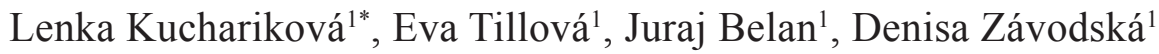

Received 23 July 2017; accepted 19 February 2018

\begin{abstract}
The self-hardening aluminum alloys are interesting for producers of casting, because these materials have the required properties without using heat treatment. This casts production result in the following advantages: energy saving, reduction of the costs, no permanent deformation, largest casting dimensions possible, and so on. Nevertheless, it is well known that improvement of mechanical properties and structure of aluminum alloys can often significantly increase the lifetime of casting and reduce costs for fuel and reduction of environmental loading. The basic and energy saving method for improvement of mechanical properties of self-hardened alloys is surface hardening. Surface hardening improves properties such as: corrosion resistance, wear resistance and hardness. In regards this facts great interest in reducing the cost of components makes a great opportunity for use laser surface processing. Therefore this article deals with using laser surface heating and evaluations its influence onto mechanical properties of self-hardening ENAC-71100, i.e. AlZn10Si8Mg cast alloy. This alloy is especially used for engine and vehicle constructions, hydraulic unit and mound so the surface properties are important for application in industries. The results show that laser surface heating have influence on properties, but well defined conditions of heating are very important.
\end{abstract}

\section{Keywords}

Al-Zn-Si cast alloys, laser surface heating, self-hardening aluminum alloys, quantitative assessment

\footnotetext{
${ }^{1}$ Department of Materials Engineering,

Faculty of Mechanical Engineering,

University of Žilina,

Univerzitná 8215/1, 01026 Žilina, Slovakia

*Corresponding author, e-mail: lenka.kucharikova@fstroj.uniza.sk
}

\section{Introduction}

Aluminum cast alloys belong to materials which are used for many applications in almost every industry. These materials are profitable for each industry field thanks to the costs, the high mechanical properties, the ductility, the good corrosion resistance etc. and so they can be used as replacements of steels and cast iron for the production of components (Eperješi et al., 2014; Uhríčik et al., 2014; Alfieria et al., 2015; Rosso et al., 2013; Rosso et al., 2014; Castella, 2015). Generally, these alloys contain high percentage of alloying elements that form a structural components. Therefore is necessary to use modification, grain refining, heat treatment, etc. for affecting the morphology of structural components and also for influencing properties such as strength, ductility, fracture toughness, thermal stability, residual stresses, dimensional stability, resistance to corrosion, and stress corrosion cracking in most aluminum cast alloys (Castella, 2015; Rosso et al., 2016; Hurtalová and Tillová, 2015; Hurtalová et al., 2015).

Last few decades is a high tendency to minimize the energy consumption in order to have a minor impact on the environment and therefore is a great effort to use instead of secondary aluminum alloys, self-hardening aluminum alloys for industrial applications (Rosso et al., 2014; 2016; Castella, 2015; Peter et al., 2014; Tillová et al., 2015; Hirsch, 2009; 2011; 2014). Selfhardening aluminum alloys have high mechanical properties without needs of heat treatment, because these materials are subjected to a natural ageing phenomenon at room temperature after casting for a storage period of about 7-10 days (Rosso et al., 2013; 2014; Peter et al., 2014; Tillová et al., 2017) and achieve the desired properties for application in different industrial fields. However, sometimes a request for reduce wear, better mechanical, fatigue properties and corrosion resistance of self-hardening aluminum is, that alloys are exposed to surface treatment (Tillová et al., 2017; Montealegre et al., 2010; Pliszka et al., 2016; Radek, 2008; Bergant et al., 2016; Spadaro et al., 2007). One of the surface treatment possibility is laser surface heating = laser hardening (Fig. 1) which is used to reduce wear and improve fatigue resistance of products especially where hard surface layers are required on tough and possibly cheap base materials and where no measurable thermal 
distortion is allowed. At nowadays, there are three major types of laser sources: $\mathrm{CO}_{2}$ lasers; $\mathrm{Nd}$ : YAG lasers; and excimer lasers (Tillová et al., 2017; Montealegre et al., 2010; Parker, 2010; Bauernhuber et al., 2016; Markovits et al., 2013). The fundamental problem in surface heating substances by laser radiation is well defined conditions of heating. Therefore, it is necessary to specify the wavelength of laser type to be used, the shape of the laser beam, for the interaction of laser radiation and matter, and we cannot forget the side effects accompanied with given technological operation (Tillová et al., 2017; Wang et al., 2000).
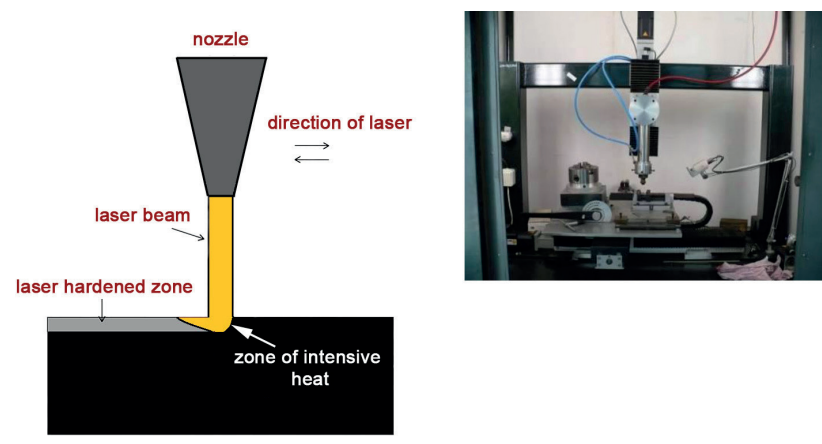

Fig. 1 Laser surface hardening with Nd:YAG laser

The present study is focused on self-hardening Al-Zn-Si aluminum alloy which can be used for casting new products for mechanical engineering, hydraulic castings, textile machinery parts, car components, and so on (Peter et al., 2014; Tillová et al., 2017). Therefore is necessary to study possibilities of increasing properties of these alloys and one way is laser surface hardening.

\section{Experimental material}

As an experimental material was used secondary self-hardening AlZn10Si8Mg cast alloy which is characterized by very good casting properties, good wear resistance, low thermal expansion and very good machining, polishability, and weldability (Rosso et al., 2013; 2014; Peter et al., 2014; Tillová et al., 2017). The experimental material, with chemical composition (in wt. \%) $9.6 \% \mathrm{Zn}, 8.64 \% \mathrm{Si}, 0.1143 \% \mathrm{Fe}, 0.181 \% \mathrm{Mn}$, $0.452 \% \mathrm{Mg}, 0.0622 \% \mathrm{Ti}, 0.0022 \% \mathrm{Ni}, 0.005 \% \mathrm{Cu}, 0.0014 \%$ $\mathrm{Cr}$, balance $\%$ of $\mathrm{Al}$, has been produced by gravity casting into the sand molds without modifying or grain refining in foundry Zátor, Ltd. Czech Republic. Experimental material was received in the form of bars (with dimensions: ø $20 \mathrm{~mm}$, length $300 \mathrm{~mm}$ ) which were after a natural ageing phenomenon at room temperature after casting for a storage period of about 10 days.

\section{Experimental procedure}

Samples for metallographic observation and laser treated layer quantification were sectioned from the mechanical test specimens and prepared via standard procedures (wet ground on SiC papers, DP polished with $3 \mu \mathrm{m}$ diamond pastes followed by Struers Op-S) and etched first by standard reagents (Keller, HF-hydrogen fluoride) and next by color reagent (Weck-Al,
MA- Ammonium molybdate) for better highlighting the laser treated layer. The microstructures and laser treated layer were studied using an optical microscope (Neophot 32) under 50x, 100x, 500x and 1 000x magnification. The quantitative analysis of laser treated layer was made using optical microscope and Image analysis software NIS Elements 4.2. The results of quantitative analysis represent the measured values on about twenty-five field of each sample.

Specimens for mechanical properties testing were made from bars (ø $20 \mathrm{~mm}$ x $300 \mathrm{~mm}$ ) with turning and milling operation (Fig. 2a). Mechanical characteristics were measured according to standards: STN EN 10002-1, STN EN ISO 100045-1, STN EN ISO 6506-1 and STN EN ISO 6507-1. Tensile strength (UTS) was measured on testing machine WDW 20 with the evaluation software Win WDW and the shift operation was $2 \mathrm{~mm}$. Bending impact test was performed on Charpy pendulum hammer (with max. energy $30 \mathrm{~J}$ ). Hardness measurement for experimental alloy was performed by a Brinell hardness tester with a load of $62.5 \mathrm{kp}(1 \mathrm{kp}=9.81 \mathrm{~N}), 2.5 \mathrm{~mm}$ diameter ball and a dwell time of 15s (HBW 2.5/62.5/15) and Vickers hardness tester with a load of $98.7 \mathrm{kp}(1 \mathrm{kp}=9.81 \mathrm{~N})$ and a dwell time of $10 \mathrm{~s}$ (HV 10). The evaluated UTS, HBW and HV reflect average values of at least six separately experimental specimens.

The microhardness of laser treated layer and structural parameters (eutectic and $\alpha$-phase $=$ matrix) was measured with using Vickers microhardness testing machine ZWICK/ Roel $\mathrm{ZH} \mu$ with the evaluation software ZWICK/Roel ZH $\mu / \mathrm{HD}$ under a $5 \mathrm{~g}$ load for $10 \mathrm{~s}$ (HV 0.05) on metallographic samples.

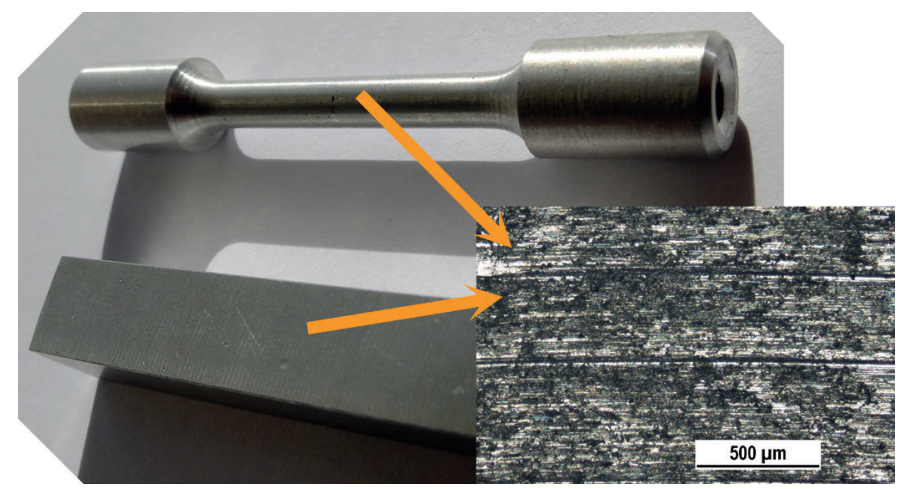

a) Samples without laser surface heating, after milling

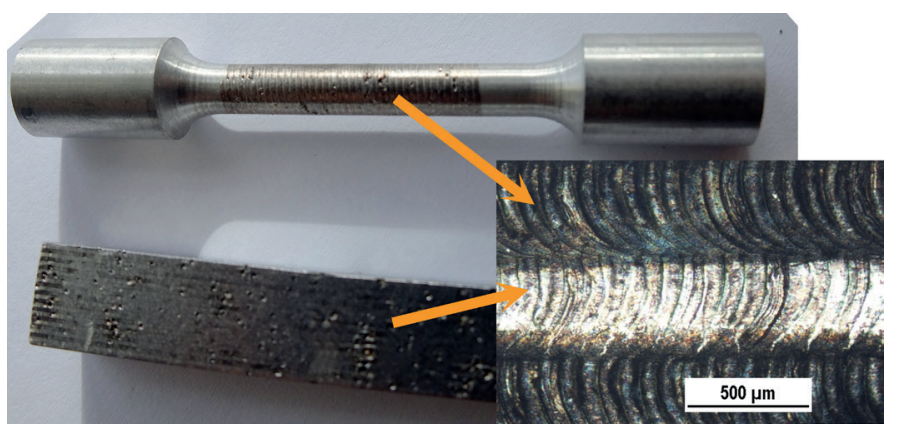

b) Samples with laser surface heating

Fig. 2 Samples for mechanical tests 
The evaluated HV 0.05 reflect average values of at least ten measurements on each structural parameter.

The laser surface heating was carried out on samples for mechanical testing (Fig. 2b) in collaboration with the Centre for Laser Technologies of Metals, Kielce, Poland. The subsequent laser heating was performed with the aid of a BLS 720 laser system employing the Nd: YAG type laser operating in the pulse mode. The parameters for the laser surface heating were: laser spot diameter $0.7 \mathrm{~mm}$, beam shift rate $250 \mathrm{~mm} / \mathrm{min}$, nozzle-sample distance $6 \mathrm{~mm}$, pulse duration $0.4 \mathrm{~ms}$, frequency $50 \mathrm{~Hz}$, protective gas-nitrogen $25 \mathrm{l} / \mathrm{min}$, shift of beam $0.4 \mathrm{~mm}$, laser average power $50 \mathrm{~W}$ and $80 \mathrm{~W}$. After the laser surfaces heating the mechanical properties were measured, next the samples were sectioned and structuraly analyzed.

\section{Experimental results and discussion}

The mechanical properties are influencing with porosity and morphology of structural particles to a large extent in all aluminum alloys, therefore was assessment of experimental samples microstructure made.

The microstructure of experimental material AlZn10Si8Mg cast alloy consists of a $\alpha$-solid solution (matrix), a eutectic mixture of $\alpha$-matrix and spherical phases (silicon particles) and variously type's intermetallic phases.

The $\alpha$ - matrix precipitates from the liquid as the primary phase in the form of dendrites and is nominally comprised of $\mathrm{Al}$ and $\mathrm{Zn}$ (Fig. 3a). As was mentioned the experimental material was cast into the sand molds, therefore the large pores were observed in microstructure too (Fig. 3a). The silicon particles were observed in a typical fine and rosette-like morphology (Fig. $3 b)$, because this material was not modified or grain refined. This result about Si morphology is in accordance with previous reports for unmodified Al-Si alloys (Pedersen and Arnberg 2001; Romankiewicz and Romankiewicz, 2014).

The presence of additional elements in the Al-Zn (group $7 \mathrm{xxxx}$ ) alloys allows many complex intermetallic phases to form, such as (Seifeddine, 2007; Cao and Campbell, 2004; Shabestari, 2004):

- binary phases, e.g. $\mathrm{Mg}_{2} \mathrm{Si}, \mathrm{Al}_{2} \mathrm{Cu}$;

- ternary phases, e.g. $\mathrm{Al}_{2} \mathrm{CuMg}, \mathrm{Al}_{5} \mathrm{FeSi}, \mathrm{AlFeMn}$, $\mathrm{A}_{17} \mathrm{Cu}_{4} \mathrm{Ni}$ and $\mathrm{AlFeNi}$

- quaternary phases, e.g. cubic $\alpha-\mathrm{Al}_{15}(\mathrm{FeMn})_{3} \mathrm{Si}_{2}$ and $\mathrm{Al}_{5} \mathrm{Cu}_{2} \mathrm{Mg}_{8} \mathrm{Si}_{6}$.

These intermetallic particles had different morphologies, such as platelet or needles, skeleton- or script-like or "Chinese script" too and oval. The intermetallic phases on base iron, manganese and copper were identified in experimental material. Fe-rich intermetallics, such as AlFeMnSi phases, are formed between the $\alpha$-dendrites. The morphology of this Fe-rich phase is plate-like (thin and long brown needles in Fig. 3c) with a thickness of a few tenths of micrometers.

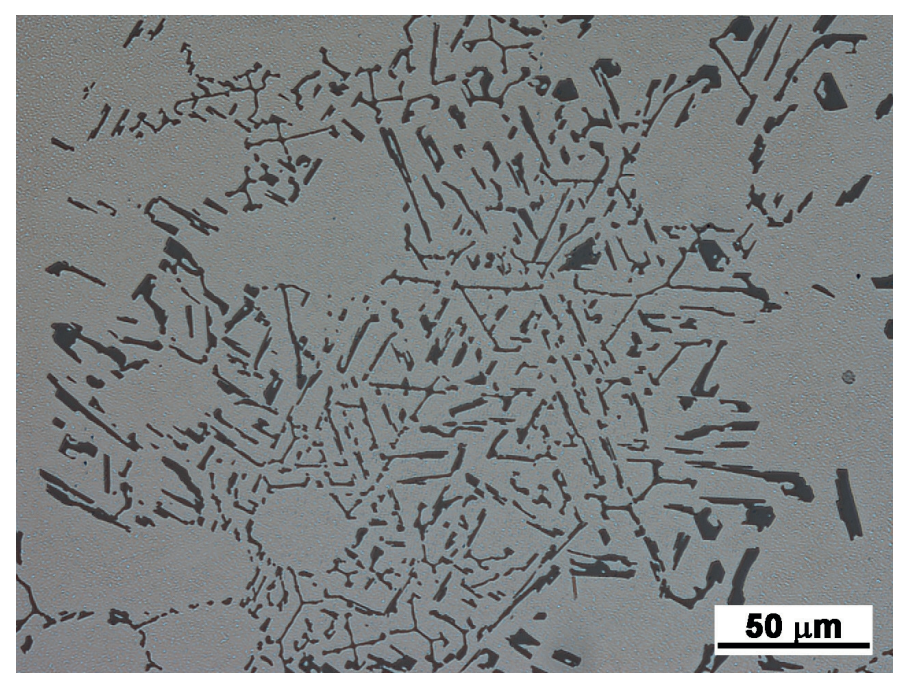

b) eutectic Si particles, etch. 0,5\% $\mathrm{HF}$

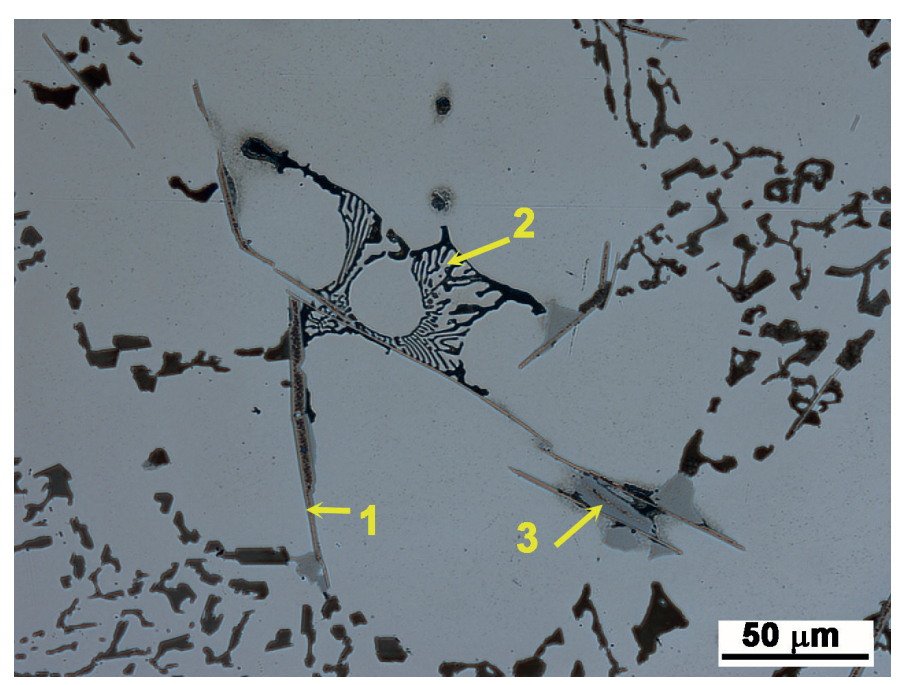

c) intermetallic phases, etch. MA;

1-AlFeMnSi, 2 - $\mathrm{Mg}_{2} \mathrm{Si}, 3-\mathrm{Al}_{2} \mathrm{CuMg}$

Fig. 3 Microstructure of experimental material 
Addition of $\mathrm{Mg}$ to experimental material leads to formation Mg-intermetallic compounds. Mg-phases can in Al-Zn-Si alloy solidify in two different forms: $\mathrm{Mg}_{2} \mathrm{Si}$ and $\mathrm{Al}_{2} \mathrm{CuMg}$. The $\mathrm{Mg}_{2} \mathrm{Si}$ phase was identified in microstructure of experimental material as individual skeleton-like or script-like so called "Chinese script" morphology (black phase - Fig. 3c). The oval round-like particles was detected as S-phase $\left(\mathrm{Al}_{2} \mathrm{CuMg}\right.$ - light grey phase Fig. 3c). Metallographic assessment of laser treated layer shows that with an increasing of the laser power, the thickness of laser treated layer - remelting zone was increased (Fig. 4a, Fig. 4b).

The thickness of laser treated layer after $50 \mathrm{~W}$ laser average power was about $57.95 \pm 0.5 \mu \mathrm{m}$ and after $80 \mathrm{~W}$ laser average power about $94.39 \pm 0.5 \mu \mathrm{m}$. The quantitative assessment shows that laser treated layer after $50 \mathrm{~W}$ laser average power was compact and in the layer were no-cracks, while on samples after $80 \mathrm{~W}$ laser average power were observed areas with cracks in layer (Fig. 5). These cracks may act as concentrator which led to failure of material. Also these defects probably cause decreasing of mechanical and fatigue properties which was shown in the work Bokůvka et al. (2011). This assessment shows that is very important to have well defined conditions of heating.

The previous studies show that sand casting alloy AlZn10Si8Mg achieve high values for tensile strength $(190 \div 250 \mathrm{MPa})$, offset $0.2 \%$ yield stress $(170 \div 230 \mathrm{MPa})$, however the low ductility limits $(1 \div 2 \%)$, hardness HB $90 \div 100$ and fatigue resistance $(80$ $\div 100 \mathrm{MPa}$ ) (Tillová et al., 2015; 2017). The assessments of basic mechanical properties of experimental material shows that laser surface heating have effect on these properties (Fig. 6).

Ultimate tensile strength increases from $167 \mathrm{MPa}$ (on samples without laser heating) to $195 \mathrm{MPa}$ after laser surface heating at $50 \mathrm{~W}$ laser average power, but at laser average power $80 \mathrm{~W}$ decreases to $162 \mathrm{MPa}$. The decreasing is probably due to the presence of cracks in laser treated layer and porosity in material (Fig. 5), because the structure was comparable for each condition of experimental material. The iron creates still the same intermetallic phases and silicon particles morphology was the same, too. The hardness measurements (Brinell and Vickers) show that highest hardness was on samples laser surface heating at $80 \mathrm{~W}$ laser average power (117 HBW, $116 \mathrm{HV}$ ) and lower at samples without laser heating (96 HBW, $106 \mathrm{HV}$ ) (the increasing was about $8 \%$ ). The result is, with the increase of the laser average power the hardness increase too, because increase of the thickness and the width of remelting zone.

Microhardness of the structural parameters (Fig. 7a, Fig. 7b) are: $\alpha$-phase 73 HV 0.05 and eutectic 89 HV 0.05 . These values were measured for all samples from experimental material with and without heat treatment. The microhardness of laser treated surface layer after $50 \mathrm{~W}$ laser average power was $109 \mathrm{HV} 0.05$ and for laser treated layer after 80W laser average power was $110 \mathrm{HV} 0.05$ (Fig. 7c).

The results show that experimental samples have comparable microhardness of surface laser treated layer after heating.

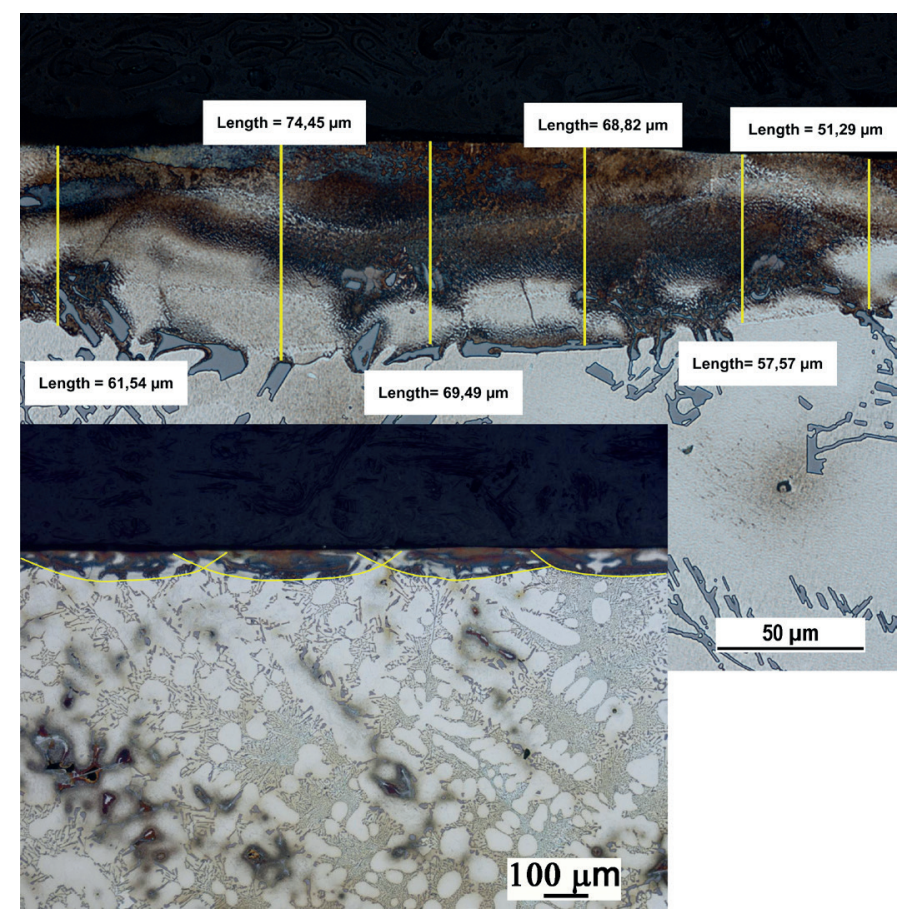

a) $50 \mathrm{~W}$ laser average power, etch. Weck-Al

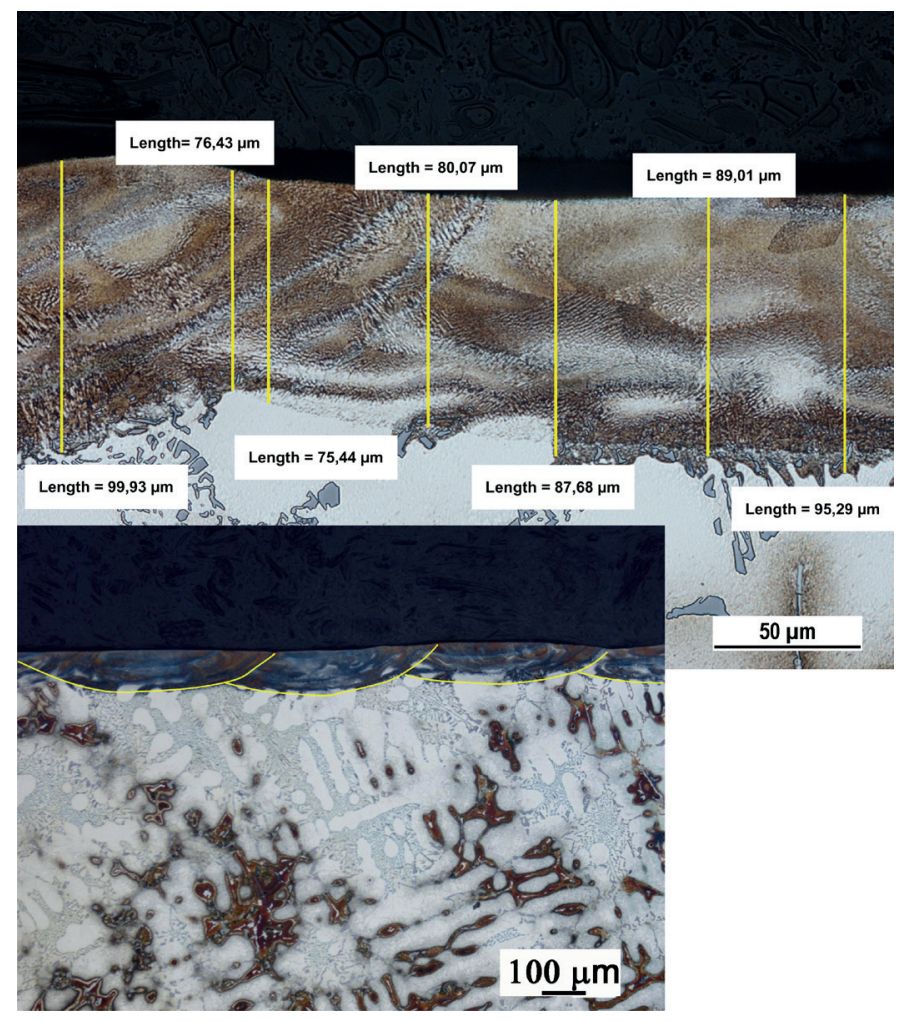

b) $80 \mathrm{~W}$ laser average power, etch. Weck-Al

Fig. 4 Quantitative assessment of laser treated layer after laser surface heating

It is probably related with the presence of thermal cracks in the laser surface (Fig. 5). Also the laser treated layer is harder than the microstructure of experimental material. Therefore it is the assumption that the laser treated layer ensure the wear reducing, increasing fatigue properties and corrosion resistance of experimental material. 


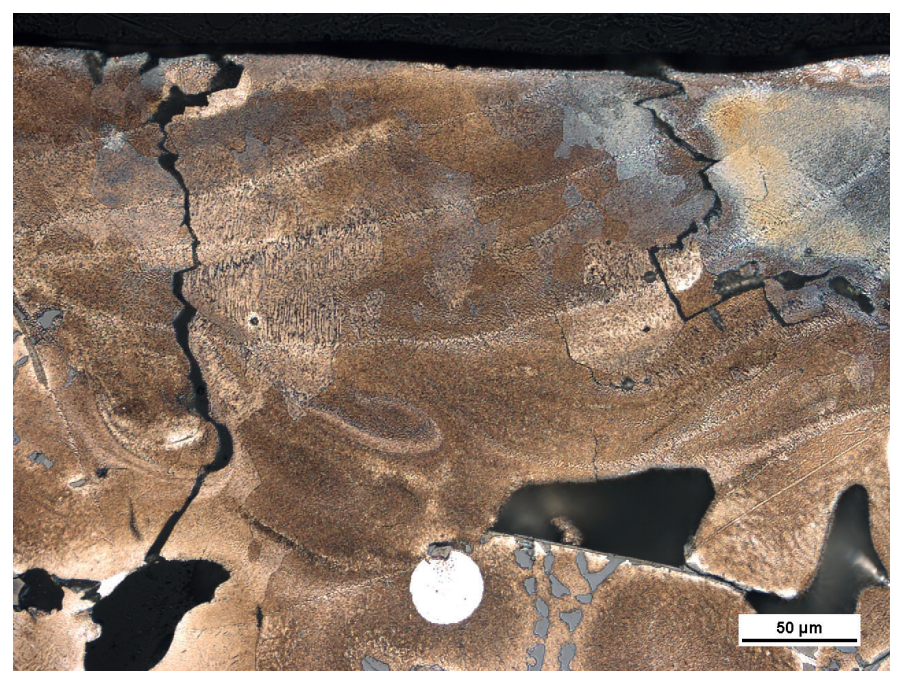

Fig. 5 Cracks in laser treated layer after $80 \mathrm{~W}$ average power, etch. Weck-Al

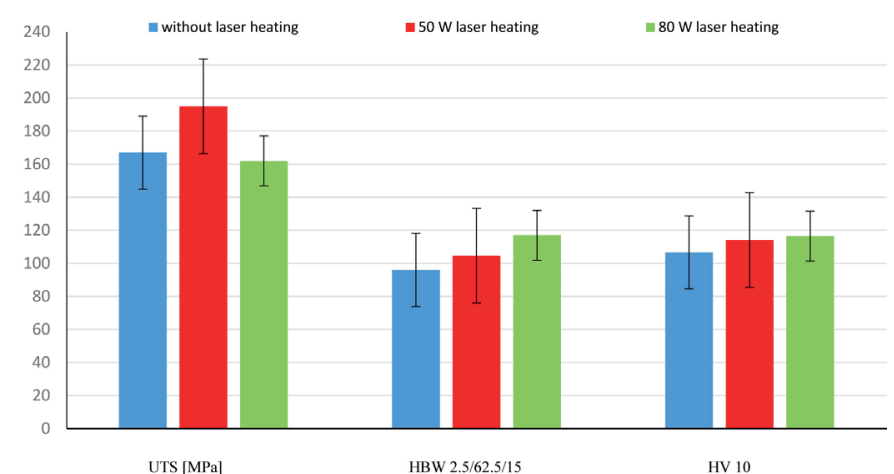

Fig. 6 An overview of basic mechanical properties of experimental material

\section{Conclusion}

The results presented a few facts about influence of laser surface heating on basic mechanical properties in the self-hardening AlZn10Si8Mg cast alloy. Therefore, the complexes conclusion about influence of laser surface heating on properties of experimental material cannot be summarized. There have been observed these results:

- The microstructure of experimental material AlZn$10 \mathrm{Si} 8 \mathrm{Mg}$ cast alloy, consist of primary phase ( $\alpha$-matrix), eutectic (mixture of $\alpha$-matrix and fine spherical Si-particles) and intermetallic phases on base $\mathrm{Fe}, \mathrm{Cu}$ and $\mathrm{Mg}$.

- The quantitative assessment of laser treated layer shows that after $50 \mathrm{~W}$ laser average power the laser treated layer is smaller than samples after $80 \mathrm{~W}$ laser average power, but layers after $80 \mathrm{~W}$ laser average power have areas with cracks, which is not acceptable.

- Ultimate tensile strength was the highest on samples after laser surface heating at $50 \mathrm{~W}$ laser average power, but at laser average power $80 \mathrm{~W}$ it was decreased. The decreasing is probably due to the presence of cracks in laser treated layer and porosity in material. The hardness measurements (Brinell and Vickers) show that highest hardness was on samples laser surface heating at $80 \mathrm{~W}$

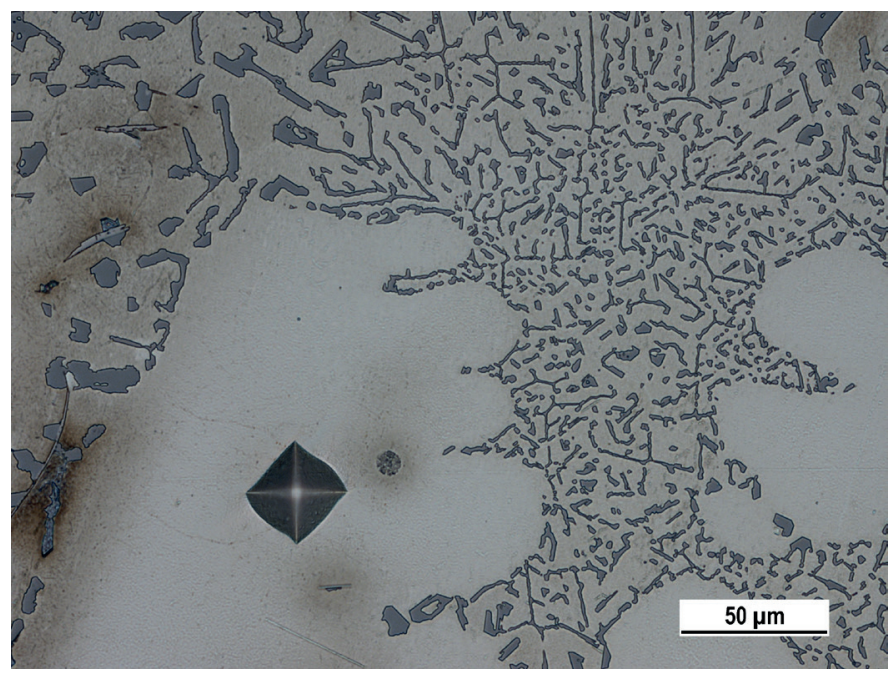

a) $\alpha$-phase

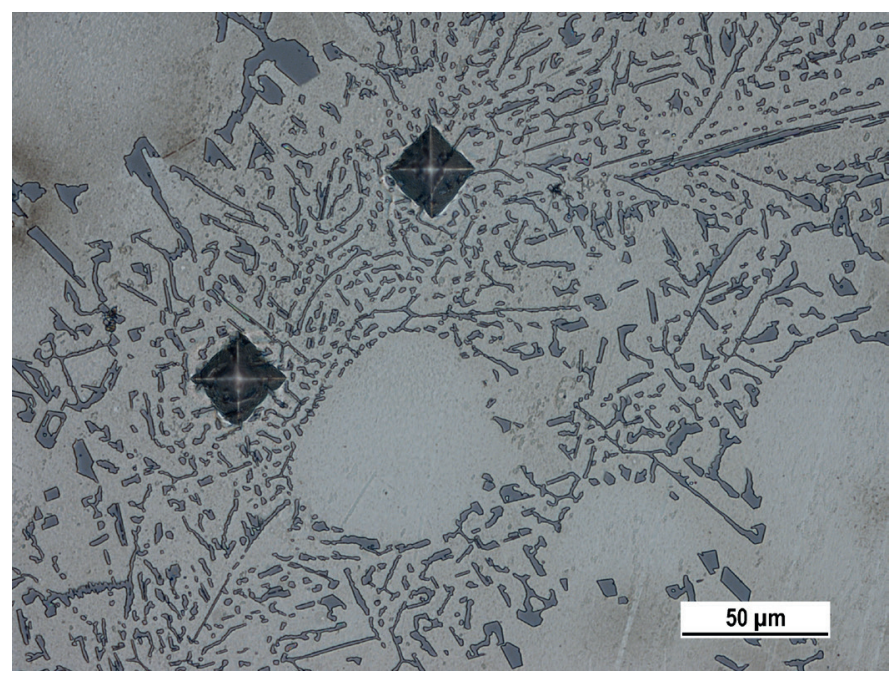

b) eutectic

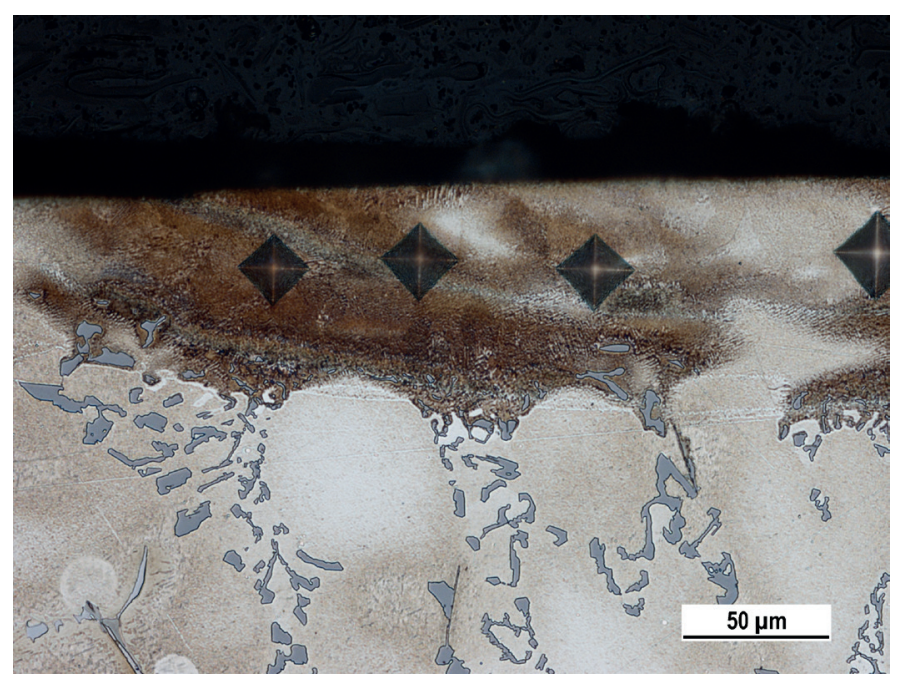

c) laser treated layer

Fig. 7 Microhardness of structural parameters and laser treated layer

laser average power and lower at samples without laser heating (the increasing was about $8 \%$ ). 
- Microhardness tests show that laser treated layer have higher microhardness in comparison with hardness other structural parameters in microstructure of experimental material, which probably increase wear and fatigue resistance of casts form this experimental material.

Considering the partial results about influence of surface heating with laser on properties of self-hardening aluminum alloys casts, with accent to minimize the energy consumption to have a minor impact on the environment, is lower laser average power using more effective to achieve the desired properties.

\section{Acknowledgement}

This study has been supported by the Scientific Grant Agency of the Ministry of Education of the Slovak Republic VEGA 01/0533/15, KEGA 044ŽU-4/2017 and European Union project ITMS 26220220154.

\section{References}

Alfieria, V., Caiazzoa, F., Sergi, V. (2015). Autogenous Laser Welding of AA 2024 Aluminum Alloy: Process Issues and Bead Features. Procedia CIRP. 33, pp. 406-411.

https://doi.org/10.1016/j.procir.2015.06.094

Bauernhuber, A., Markovits, T., Takács, J. (2016). Investigating the Pulse Mode Laser Joining of Overlapped Plastic and Metal Sheets. Physics Procedia. 83, pp. 1094-1101. https://doi.org/10.1016/j.phpro.2016.08.115

Bergant, Z., Trdan, U., Grum, J. (2016). Effects of laser shock processing on high cycle fatigue crack growth rate and fracture toughness of aluminum alloy 6082-T651. International Journal of Fatigue. 87, pp. 444-455. https://doi.org/10.1016/j.ijfatigue.2016.02.027

Bokůvka, O., Palček, P., Chalupová, M., Żórawski, W. (2011). Fatigue properties of structural steel after laser treatment. Zeszyty Naukowe Politechniki Swietokrzyskiej. Nauki Techniczne. 16, pp. 11-17.

Cao, X., Campbell, J. (2004). The solidification characteristics of Fe-rich intermetallics in Al-11.5Si-0.4Mg cast alloys. Metallurgical and Materials Transactions A. 35(5), pp. 1425-1435. https://doi.org/10.1007/s11661-004-0251-0

Castella, C. (2015). Self-hardening aluminum alloys for automotive applications. PhD. Thesis. Politechnico di Torino. Turin, Italy. https://doi.org/10.6092/polito/porto/2598757

Eperješi, Š., Matvija, M., Eperješi, l'., Vojtko, M. (2014). Evaluation of Cracking Causes of A1Si5Cu3 Alloy Castings. Archives of Metallurgy and Materials. 59(3), pp. 1089-1092.

https://doi.org/10.2478/amm-2014-0187

Hirsch, J. (2009). Aluminium in Innovative Light-Weight Car Design. In: Proceedings of the International Conference "Innovative Development for Lightweight Vehicle Structures." Wolfsburg, Germany, organized by Volkswagen Group, May 26-27, 2009. p. 101.

Hirsch, J. (2011). Aluminium in Innovative Light-Weight Car Design. Materials Transactions. 52(5), pp. 818-824.

http://doi.org/10.2320/matertrans.L-MZ201132

Hirsch, J. (2014). Recent development in aluminum for automotive applications. Transactions of Nonferrous Metals Society of China. 24(7), pp. 1995-2002. https://doi.org/10.1016/S1003-6326(14)63305-7

Hurtalová, L., Tillová, E. (2015). The Modified AISi7Mg0.3 Cast Alloy Mechanical Properties Changes at Different Testing Temperatures. Key En- gineering Materials. 635, pp. 13-17.

https://doi.org/10.4028/www.scientific.net/KEM.635.13

Hurtalová, L., Tillová, E. Chalupová, M. (2015). Possibilities of Fe-rich phases elimination with using heat treatment in secondary Al-Si-Cu cast alloy. Metalurgija. 54(1), pp. 39-42.

http://hrcak.srce.hr/126669

Markovits, T., Bauernhuber, A., Mikula, P. (2013). Study on the transparency of polymer materials in case of Nd:YAG laser radiation. Periodica Polytechnica Transportation Engineering. 41(2), pp. 149-154.

https://doi.org/10.3311/PPtr.7117

Montealegre, M. A., Castro, G., Rey, P., Arias, J. L., Vázquez, P., González, M. (2010). Surface Treatments by Laser Technology. Contemporary Materials. 1(1), pp. 19-30.

https://doi.org/10.5767/anurs.cmat.100101.en.019M

Parker, K. (2010). Laser hardening heats up. [Online] Available from: http:// www.industrial-lasers.com/articles/print/volume-250/issue-6/features/ laser-hardening-heats-up.html [Accessed 24th March 2017]

Peter, I., Rosso, M., Castella, C., Molina, R. (2014). Self-Hardening A1loys for Automotive Application. Materials Science Forum. 794-796, pp. 1221-1226.

https://doi.org/10.4028/www.scientific.net/MSF.794-796.1221

Pliszka, I., Radek, N., Gądek-Moszczak, A., Fabian, P. (2016). Practical use of the surface layers of laser modified WC-Cu coatings. Tribologia. 6, pp. 121-130.

Radek, N. (2008). Experimental investigations of the $\mathrm{Cu}-\mathrm{Mo}$ and $\mathrm{Cu}-\mathrm{Ti}$ electro-spark coatings modified by laser beam. Advances in Manufacturing Science and Technology. 32(2), pp. 53-68.

Pedersen, L., Arnberg, L. (2001). The effect of solution heat treatment and quenching rates on mechanical properties and microstructures in AlSiMg foundry alloys. Metallurgical and Materials Transactions A. 32(3), pp. 525-532. https://doi.org/10.1007/s11661-001-0069-y

Rheinfelden Alloys (2013). Primary aluminum Casting Alloys. Leporello. edition 5/2013. Rheinfelden Alloys GmbH \& Co. KG, Rheinfelden, Germany.

Romankiewicz, R., Romankiewicz, F. (2014). The influence of modification for structure and impact resistance of silumin AlSi11. Production Engineering Archives = Archiwum Inżynierii Produkcji. 3(2), pp. 6-9.

Rosso, M., Peter, I., Castella, C. (2013). Investigation on AlZn10Si8Mg alloys for automotive application. Metallurgical Science and Technology. 61(2), pp. 62-68.

Rosso, M., Peter, I., Castella, C., Molina, R. (2014). Properties of AlZn10Si8Mg Alloys for High Performances Application. Light Metals 2014. pp. 213-218 https://doi.org/10.1007/978-3-319-48144-9_37

Rosso, M., Peter, I., Castella, C., Lombardo, S. (2016). Grain refinement of self-hardening aluminum alloys. Light Metals 2016. pp. 705-710. https://doi.org/10.1007/978-3-319-48251-4_118

Seifeddine, S. (2007). The influence of Fe on the microstructure and mechanical properties of cast Al-Si alloys. Literature review - Vilmer project. Jönköping University, Sweden.

Shabestari, S. G. (2004). The effect of iron and manganese on the formation of intermetallic compounds in aluminum-silicon alloys. Materials Science and Engineering: A. 383(2), pp. 289-298. https://doi.org/10.1016/j.msea.2004.06.022

Spadaro, C., Sunseri, C., Dispenza, C. (2007). Laser surface treatment for adhesion improvement of aluminum alloys structure joints. Radiation Physics and Chemistry. 76(8-9), pp. 1441-1446. https://doi.org/10.1016/j.radphyschem.2007.02.047

Tillová, E., Chalupová, M., Hurtalová, L., Belan, J. (2015). Impact properties of self-hardening aluminium alloy (AlZn10Si8Mg) at elevated temperatures. Manufacturing Technology. 15(4), pp. 720-727. 
Tillová, E., Kuchariková, L., Chalupová, M., Belan, J., Vaško, A., Švecová, I. (2017). Influence of laser surface hardening on corrosion properties of Al-Zn-Si cast alloy. Metalurgija. 56(1-2), pp. 47-50. http://hrcak.srce.hr/168879

Uhríčik, M., Palček, P., Soviarová, A., Snopiński, P. (2014). Change of Internal Friction on Aluminium Alloy with $10.1 \% \mathrm{Mg}$ Dependence on the Temperature. Manufacturing Technology. 14(3), pp. 467-470.

Wang, X., Takács, J., Krallics, Gy., Szilágyi, A., Markovits, T. (2000). Experimental Research on Laser-Material Interaction. Periodica Polytechnica Transportation Engineering. 28(1-2), pp. 143-152. 